\title{
The 0-2A Progenitor during Development and Remyelination
}

Monique Dubois-Dalcq, Regina Armstrong, Bryn Watkins and Randall McKinnon

\author{
National Institute of Neurological Disorders and Stroke \\ Laboratory of Viral and Molecular Pathogenesis \\ Building 36, Room 5D-04 \\ Bethesda, Maryland 20892
}

We are investigating the factors controlling growth and differentiation of oligodendrocytes precursor cells during CNS myelination and remyelination. These studies have stemmed from the description of $0-2 A$ progenitor cells in the newborn rat optic nerve (reviewed in Raff, 1989). These progenitor cells are bipotential since they can differentiate either into oligodendrocytes, which form myelin in the CNS, or type 2 astrocytes, which extend processes to nodes of Ranvier. Therefore, the lineage derived from this progenitor is called the oligodendrocyte-type 2 astrocyte (O-2A) lineage. 0-2A progenitor cells are identified by immunolabeling with an antibody to cell surface gangliosides ( $\mathrm{A}_{2} \mathrm{~B}_{5}$ ) or glycoproteins (NSP4). O-2A progenitor cells purified and cultured from newborn rat brain (Behar et al., 1988) are shown in Figure 1.

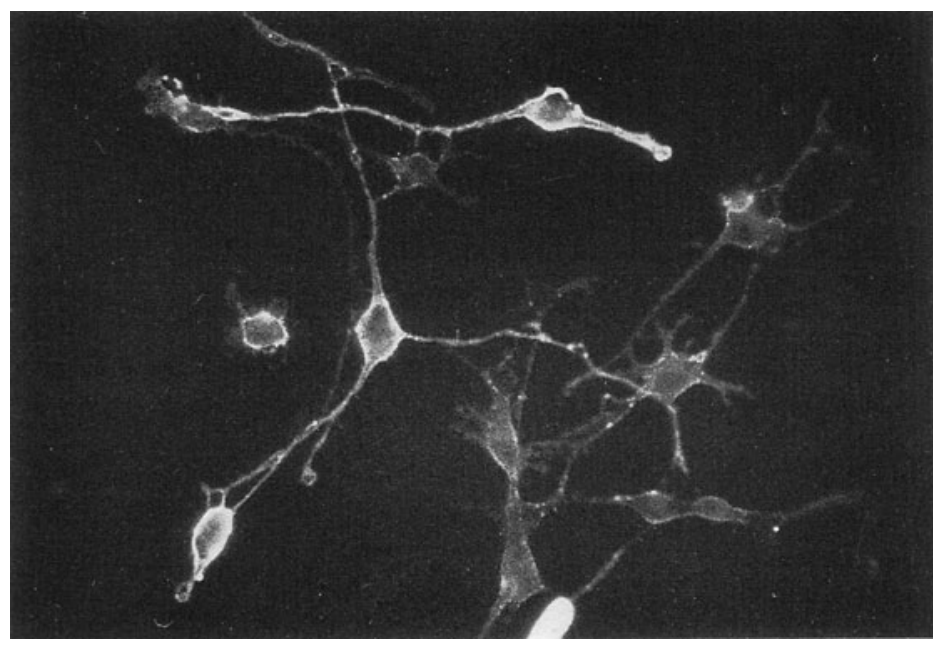

Figure 1. Purified brain $\mathrm{O}-2 \mathrm{~A}$ progenitors in culture stained with NSP4 antibody. Cells are bipolar or multipolar with short processes. 
In this short report of our ongoing studies, we describe how O-2A progenitor cells from the rodent CNS move along the oligodendrocyte differentiation pathway during development in vitro, and the role of polypeptide growth factors including plateletderived growth factor (PDGF) and fibroblast growth factor (FGF) in the growth and rate of differentiation of this progenitor cell. We will also review the evidence for the persistence of $\mathrm{O}-2 \mathrm{~A}$ progenitors in the rodent adult nervous system and how these cells react to a demyelinating episode and may play a role in remyelination.

\section{DEVELOPMENT}

Earlier studies on newborn rat optic nerve have shown that O-2A progenitor cells cultured in defined medium quickly develop into oligodendrocytes expressing galactocerebroside (GC), a major myelin glycolipid (Raff et al.: 1983). In contrast, addition of $10 \%$ fetal bovine serum (FBS) drives the cell along the type 2 astrocyte pathway and induces glial fibrillary acidic protein (GFAP) expression. This situation is different in vivo: $0-2 A$ progenitors give rise to the first oligodendrocytes around birth while they keep proliferating for at least the next 2 weeks (Skoff et al., 1976). Conditioned medium (CM) derived from type 1 astrocytes, the first type of astrocyte emerging in the brain early before birth, restores this normal sequence of events in vitro: the progenitor will go through a number of divisions in vitro as they do in vivo before they differentiate (Raff et al., 1985). One question raised by these studies (reviewed in Raff, 1989) is whether the $\mathrm{O}-2 \mathrm{~A}$ progenitor is committed to become an oligodendrocyte after a set number of divisions or whether it is a true stem cell, capable of self renewal in addition to generating oligodendrocytes. The best way to address this question is to perform cultures of single O-2A progenitors and analyse the progeny derived from clonal expansion of single cells.

\section{A. Clonal Analysis of the $\mathrm{O}-2 \mathrm{~A}$ progenitor}

Initial studies by Temple and Raff (1986) on O-2A progenitors seeded singly on a layer of type 1 astrocytes indicated that the $0-2 A$ progenitor divides a set number of times during 8-10 days before its progeny become multipolar differentiated oligodendrocytes. In similar experiments, we seeded single progenitor cells from either optic nerve or cerebrum onto monolayers of type 1 astrocytes (Dubois-Dalcq, 1987; McMorris and Dubois-Dalcq, 1988). We selected the larger clones at 8 days and followed them for up to 
3 weeks in culture. Clonal growth progressed steadily during the first week ( 1 division per day) then slowed considerably. The majority of the clones were still expanding at 3 weeks and contained a variable ratio of multipolar cells reacting with A2B5 antibody but not expressing GC. In addition these GC negative cells stained with the $\mathrm{O} 4$ antibody, which recognized sulfatide and another glycolipid that are present on the surface of the $0-2 \mathrm{~A}$ progenitor at a later stage along the pathway. These $04+$ cells had a more complex morphology and did not express vimentin. Gard and Pfeiffer (1989) have also described a population of $04+$ multipolar cells which did not acquire GC 10 days after sorting and culture. Our clonal analysis demonstrated that the relative abundance of multipolar $\mathrm{O} 4+\mathrm{GC}$ - cells was increased when insulin was deleted from defined medium, while many more oligodendrocytes formed in the presence of insulin $(5 \mu \mathrm{g} / \mathrm{ml})$ or $1 \mathrm{GF} 1(100 \mathrm{ng} / \mathrm{ml})$ (McMorris and Dubois-Dalcq, 1988). In the presence of these factors, some clones contained only GC+ cells as described by Temple and Raff (1986). These studies indicated that progenitor cells can be expanded for a prolonged period of time in vitro, as in vivo studies had suggested. Furthermore IGF1 can promote proliferation of this $\mathrm{O} 4+$ progenitor and induces these cells to develop into oligodendrocytes (McMorris and DuboisDalcq,1988).

\section{B. PDGF and the O-2A Lineage}

The recent observations that type 1 astrocytes synthesize PDGF transcripts and protein and that anti-PDGF antibodies can neutralize the mitogenic effect of type 1 astrocyte $C M$ have suggested a key role of PDGF in the growth of O-2A progenitors (Richardson et al., 1988). PDGF is active as a dimer and composed of 2 chains, designated $A$ and $B$. The gene coding for PDGF-A chain in man is on chromosome 7, and the $B$ chain gene is on chromosome 22 (reviewed in Ross et al., 1986). All three dimeric forms of PDGF have been identified and are biologically active, such as PDGF $A B$ from human platelets, $B B$ from porcine platelets and $A A$ from osteosarcoma cells. Recent studies have identified both the PDGF ligands and PDGF receptors that are importani for 0-2A progenitor development in the rat CNS. These results are summarized in Table 1. As mentioned above, type 1 astrocytes are the major source of PDGF ( $A$ chain) in the rat, although it is not excluded that $0-2 A$ progenitor cells and or oligodendrocytes can also synthesize small amounts of PDGF. In the developing rat CNS, the A chain transcripts start to be expressed at E17 and 
Table I. PDGF ligands and receptors in O-2A lineage cells*

\begin{tabular}{|c|c|c|c|}
\hline & $\begin{array}{r}\text { Type-1 } \\
\text { Astrocyte }\end{array}$ & $\begin{array}{c}\mathrm{O}-2 \mathrm{~A} \\
\text { Progenitor }\end{array}$ & Oligodendrocy \\
\hline $\begin{array}{l}\text { PDGF Ligands: } \\
\text { A-chain mRNA } \\
\text { A-chain protein } \\
\text { B (sis) mRNA } \\
\text { B (sis) protein }\end{array}$ & $\begin{array}{r}++ \\
+ \\
(+)\end{array}$ & & \\
\hline $\begin{array}{c}\text { PDGF Receptors: } \\
\alpha-R \text { mRNA } \\
\alpha-R \text { protein } \\
B-R \text { mRNA } \\
B-R \text { protein }\end{array}$ & $\begin{array}{l}0 \\
0\end{array}$ & $\begin{array}{r}++ \\
++ \\
0\end{array}$ & $\begin{array}{l}+ \\
+ \\
0\end{array}$ \\
\hline $\begin{array}{l}\text { Binding assays: } \\
\text { Mitogenicity: }\end{array}$ & 0 & $\begin{array}{l}A A, A B, B B \\
A A, A B>B B\end{array}$ & $\begin{array}{c}A A, A B, B B \\
0\end{array}$ \\
\hline
\end{tabular}

increase in abundance thereafter, while low and constant levels of PDGF B transcripts are detected throughout rat brain development (Richardson et al., 1988). In addition, A chain transcripts are easily detected by in situ hybridization in the newborn rat optic nerve while the $B$ chain transcripts are not detectable in the optic nerve parenchyma (Pringle et al.,1989).

The O-2A progenitor was examined recently for the expression of PDGF receptors, members of the tyrosine-kinase family of growth factors receptors. Two types of PDGF receptors (type-A or $\alpha$; type-B or $B$ ) have been characterized (Hart et al., 1988; Heldin et al., 1988) and cDNA copies cloned (Yarden et al., 1986; Matsui et al., 1989; ClaessonWelsh et al., 1989). The $\alpha$ receptor binds all 3 dimeric forms of PDGF ( $A A, A B, B B$ ) whereas the $B$ receptor binds the $B B$ dimers with high affinity and $A B$ dimers with low affinity. Ligand binding studies have indicated that $\mathrm{O}-2 \mathrm{~A}$ progenitor cells from optic nerve express the PDGF- $\alpha$ receptor (Hart et al.,1989), and PDGF AA dimers are a more potent mitogen than BB dimers in this system (Pringle et al., 1989) as discussed by Richardson et al. in this volume. The identity of the PDGF receptor on rat O-2A progenitor cells as the $\alpha$-receptor has been confirmed by Northern blot analysis of the receptor mRNA transcripts in purified brain $\mathrm{O}-2 \mathrm{~A}$ progenitor cells. We stern blot analysis further 
determined that $\mathrm{O}-2 \mathrm{~A}$ cells express abundant levels of the $\alpha$-receptor but non-detectable levels of the PDGF- $B$ receptor (McKinnon et al., 1989). The O-2A progenitor appears to be the first example of a mammalian cell expressing only the PDGF- $\alpha$ receptor.

PDGF drives the proliferation of $\mathrm{O}-2 \mathrm{~A}$ progenitor cells from optic nerve and regulates the timing of their differentiation (Raff et al.,1988). We have examined the induction of myelin basic protein (MBP), a gene expressed in differentiated oligodendrocytes (Zeller et al., 1985), in cultures of purified brain progenitor cells treated with PDGF. PDGF delayed MBP transcript accumulation but did not prevent the expression of this differentiation gene (McKinnon et al., 1989).

\section{A Possible role for FGF in the O-2A Lineage}

Both acidic and basic FGFs are abundant in the adult CNS (reviewed by Barde, 1989) and have been shown to have mitogenic effects on oligodendrocyte precursors and possibly oligodendrocytes (Eccleston and Silberberg, 1985; Saneto and DeVellis, 1985; Besnard et al., 1989). The basic form of FGF (bFGF) has been purified from cell lysates of cultured astrocytes (Hatten et al., 1988; Ferrara et al., 1988). As shown in Fig 2, bFGF is a more potent mitogen than PDGF for purified brain O-2A progenitors as assayed by BUdR incorporation, using double immunofluorescence with A2B5 to identify progenitor cells with BUdR labeled nuclei.

Figure 2. Mitogenic response of $O-2 A$ progenitor cells to porcine PDGF-BB (pPDGF), human PDGF-AB (hPDGF), and bFGF. Purified progenitors were cultured for 24 hrs with growth factors, pulsed 2 hrs with $10 \mu \mathrm{M}$ BUdR, then stained with anti-A2B5 and anti-BUdR. Values represent the \% A2B5 positive cells that incorporated BUdR.

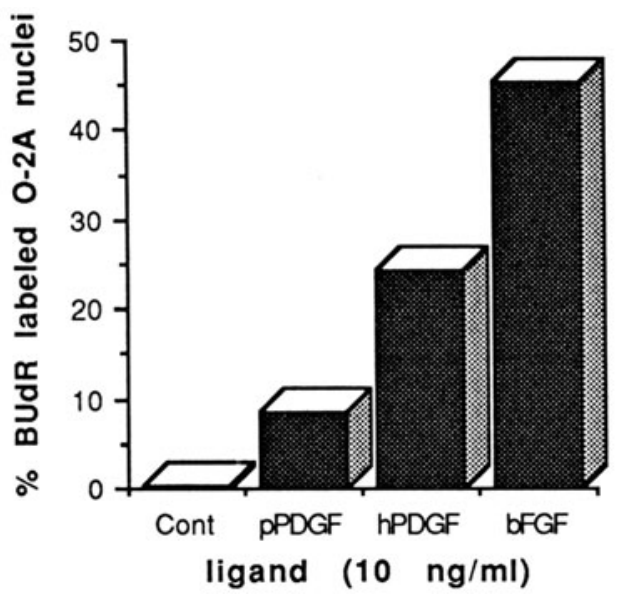


We have also used Northern blot analysis of myelin-specific gene transcripts to examine the effects of bFGF on O-2A differentiation (McKinnon et al. 1989). Expression of MBP was completely inhibited by treatment of O-2A progenitors by $10 \mathrm{ng} / \mathrm{ml} \mathrm{bFGF,} \mathrm{a}$ situation different from that seen with PDGF (see above). When both FGF and PDGF were present for 2 days, the same inhibition of MBP expression was seen. The inhibition of myelin expression was reversible when FGF was removed from the cells. FGF also induced a rapid and dramatic increase in the levels of the PDGF- $\alpha$ receptor expressed by brain O$2 \mathrm{~A}$ progenitors. We are presently examining whether this FGF induced increase in receptor levels results in an enhanced sensitivity of the progenitor cells to lower doses of the different dimeric forms of PDGF.

Our present results suggest that FGF can regulate the $0-2 A$ progenitor interactions with PDGF. Thus FGF and PDGF can influence the timing of oligodendrocyte differentiation in vitro. This indicates that a subtle interplay between these factors may set the timing of myelination in specific tracts in vivo. Since FGF appears to be increased locally in brain wounds (Finkelstein et al., 1988), this factor may also play a role in glial cell regeneration and remyelination (see below). bFGF may in fact be produced by neurons (Pettmann et al., 1986; Finkelstein et al., 1988; review by Barde, 1989) and FGFs have been shown to promote survival and neurite outgrowth of a variety of neurons (reviewed in Barde, 1989). Thus this polypeptide may successively have an effect on neuronal development and the timing of myelination of axons. Interestingly purified cultures of cerebellar interneurons secrete in their medium a factor which has mitogenic activity for O-2A progenitor cells and appears to arrest their differentiation (Levine, 1989). Whether cerebellar interneuron CM contains FGF-like factors is presently not known.

If FGF allows $0-2 A$ progenitor cells to divide for prolonged periods of time, one would postulate that other factors made in the CNS might inhibit PDGF induced mitosis. One possible candidate for this function would be transformirg growth factor B, TGF-B (Van Obberghen-Schilling et al., 1987). TGFB is synthezised by type 1 astrocytes and can decrease the number of $\mathrm{O}-2 \mathrm{~A}$ progenitors dividing in the presence of PDGF. The possibility of upregulation of the O-2A progenitor response to PDGF by one factor versus down regulation by another needs to be further explored. It would constitute an attractive mechanism by which the number of oligodendrocytes could be controlled with flexibility during development and regeneration. In addition the factc rs mentioned above may have a direct effect on the remyelination program (see below). 


\section{Remyelination}

\section{A. The Q-2A progenitor in adult CNS}

Evidence that rare $\mathrm{O}-2 \mathrm{~A}$ progenitor cells exist in the normal adult rodent $\mathrm{CNS}$ has arisen from recent studies on optic nerve, rat brain and mouse spinal cord (ffrenchConstant and Raff, 1986; Armstrong et al., 1988; Hunter et al., 1988; Wolswijk and Noble, 1989). These investigators have successfully isolated progenitor cells by enzymatic and mechanical dissociation of the nervous tissue, sometimes followed by a Percoll gradient to separate the glial cells from the myelin. The in vitro properties of the progenitors isolated from adult CNS are compared to those of the newborn progenitors in table 2. The latter differ from the adult $0-2 A$ progenitor by their antigenic phenotype, cell shape and growth potential. Adult O-2A progenitors may extend branched processes which contrast with the simple bipolar morphology of the neonatal progenitor (Wolswijk and Noble, 1989). These adult O-2A progenitors simultaneously express the glycolipids recognized by the $\mathrm{A} 2 \mathrm{~B} 5$ and $\mathrm{O} 4$ antibodies whereas the neonatal $\mathrm{O}-2 \mathrm{~A}$ progenitor stains only for A2B5 at birth and then moves on to express 04 one week later (Sommer and Noble, 1986). Vimentin is clearly present in the A2B5+ neonatal progenitor (Raff et al.,1984). However, vimentin is not detectable in adult progenitors of optic nerve. Similarly, O4+, A2B5+, vimentin- progenitors are present in 3 week old clones derived from single O-2A progenitors of newborn optic nerve and brain (Dubois-Dalcq, 1987; McMorris and Dubois-Dalcq, 1988).

Table 2. Comparison between neonatal and adult 0-2A progenitor cells of rodent CNS*.

\begin{tabular}{|c|c|c|}
\hline & Neonatal Progenitor & Adult Progenitor \\
\hline A2B5 (GQ Gangliosides) & + & + \\
\hline O4 (sulfatide other lipid) & $(-) \rightarrow(+)$ & + \\
\hline Vimentin & $(+) \rightarrow(-)$ & - \\
\hline Galactocerebroside & - & - \\
\hline Shape & $\begin{array}{l}\text { Bipolar or small } \\
\text { multipolar }\end{array}$ & $\begin{array}{l}\text { Complex } \\
\text { processes }\end{array}$ \\
\hline Cell Cycle Time & $18 \mathrm{~h}$ & $65 \mathrm{~h}$ \\
\hline Bipotentiality & + & + \\
\hline
\end{tabular}

* see text for references. 
The adult $\mathrm{O}-2 \mathrm{~A}$ progenitor of optic nerve has retained bipotentiality. It can evolve into either an oligodendrocyte or a type 2 astrocyte depending on the media conditions, but it differentiates more slowly ( $>5$ days) than the neonatal progenitor ( $<3$ days) (Wolswijk and Noble, 1989). O-2A progenitor cells in adult rodents can proliferate, although the cell cycle is lengthened relative to the neonatal O-2A progenitor (65 hours versus 18 hours) (Wolswijk, \& Noble 1989). The properties of bipotentiality and mitogenic capacity identify the adult cell as a true progenitor of the O-2A lineage which continues to exist in fully myelinated tissue.

\section{B. The Q-2A Progenitor in Remyelination}

The studies summarized above point to a potential role for the O-2A progenitor of the adult CNS in the regeneration of myelin after a demyelinating episode. The antigenic phenotype and biological properties of these precursors had not previously been described during a demyelinating disease. The fact that new oligodendrocytes are generated in reaction to a demyelinating episode of viral or toxic origin has been established in several electron microscopic studies combined with autoradiography (Herndon et al., 1977; Ludwin et al., 1981; Aranella and Herndon, 1984). Moreover, the emergence of myelin proteins and the expression of myelin genes during remyelination recapitulates the developmental program of myelination (Ludwin and Sternberger, 1984; Jordan et al., 1989a). This suggests that immature oligodendrocytes are the cells responsible for remyelinating denuded axons.

The demyelinating model we have studied is produced in $\mathrm{C} 57 \mathrm{BI} / 6 \mathrm{~N}$ mice at four weeks of age by intracerebral inoculation of the A-59 strain of mouse hepatitis virus. One week after intracranial inoculation (1 WPI), virus replication in glial cells is widespread throughout the spinal cord and results in a distinct decrtase in all myelin-specific mRNA's prior to demyelination (Jordan et al., 1989b). Areas of demyelination develop by 3 WPI. Within the lesions the number of oligodendrocytes is reduced and total MBP transcripts are decreased by $75 \%$ compared to control white matter. Virus is cleared throughout most of the spinal cord by 4 WPI. At the earliest stage of remyelination, we have described an important increase in MBP transcripts containing exon 2 (encoding pre-large and presmall forms of MBP), which are characteristic of myelination in early development (Jordan et al., 1989a). This increase in MBP transcripts containing exon 2 occurred in and around the lesions. This suggests that oligodendrocyte progenitor cells can repopulate 
the demyelinating lesions through of a process of mitosis, migration, and differentiation.

To examine this possibility further, we first attempted to detect directly in vivo $0-2 \mathrm{~A}$ lineage cells in the spinal cord of these infected mice at several stages of the demyelinating disease (Godfraind et al., 1989). We used triple-label immunofluorescence for O4, a progenitor marker, GFAP, the astrocyte marker, and 2'-3'-cyclic nucleotide 3'phosphohydrolase (CNP), an early myelin protein which stains oligodendrocytes more reliably than GC in 1 micron frozen sections. While we found rare $04+$ cells in control mice, these same cells were frequent in the spinal cord of infected mice at 1 and 2 WPI. Some of these cells were labeled with tritiated thymidine after a two hour in vivo pulse, indicating their ability to divide in response to a stimulus. Between 2 and 4 WPI, both O$2 \mathrm{~A}$ progenitors $(\mathrm{O} 4+)$ and type 2 astrocytes $(\mathrm{O} 4+$, GFAP+) were found in the lesions, and a proportion of these cells again incorporated thymidine (Godfraind et al., 1989). As remyelination proceeded, tritiated thymidine injected during the demyelinating phase appeared in CNP+ oligodendrocytes, indicating that precursor cells which divided earlier in the disease had generated new oligodendrocytes (Godfraind et al., 1989).

Encouraged by the identification of $\mathrm{O}-2 \mathrm{~A}$ lineage cells in vivo in these animals, we then isolated these cells from the spinal cord of demyelinating and remyelinating mice (Armstrong et al., 1988). O-2A lineage cells identified in cultures from adult CNS included $\mathrm{O}-2 \mathrm{~A}$ adult progenitor cells (figure 3 ), oligodendrocytes and type 2 astrocytes (figure 4).
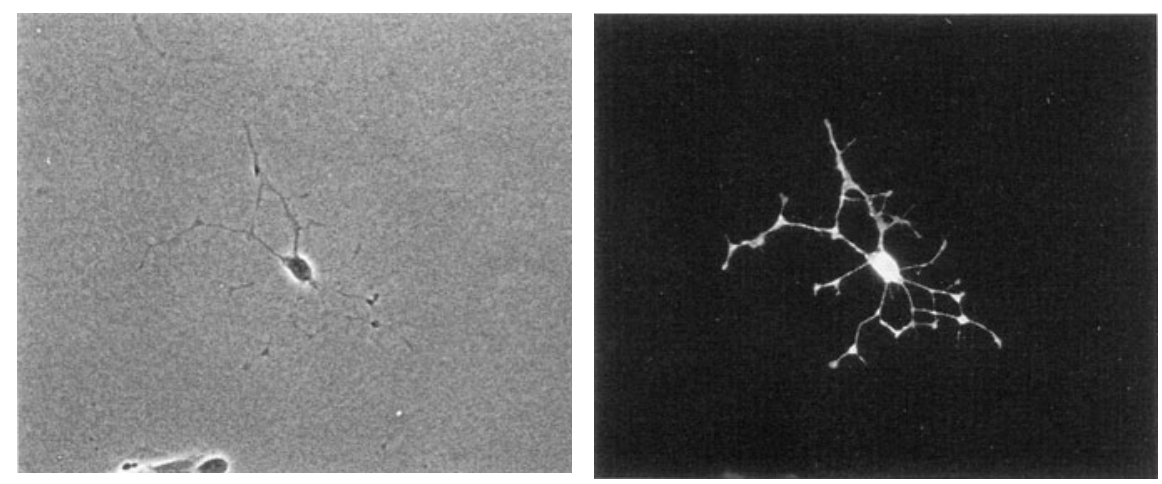

Figure 3. An O-2A progenitor cell (O4+ GC- GFAP-) isolated from spinal cords of 10 week old mice during remyelination ( $6 \mathrm{WPI})$. Cells were fixed at 3 days in vitro. Left: phase contrast. Right: $\mathrm{O} 4$ immunostain. 

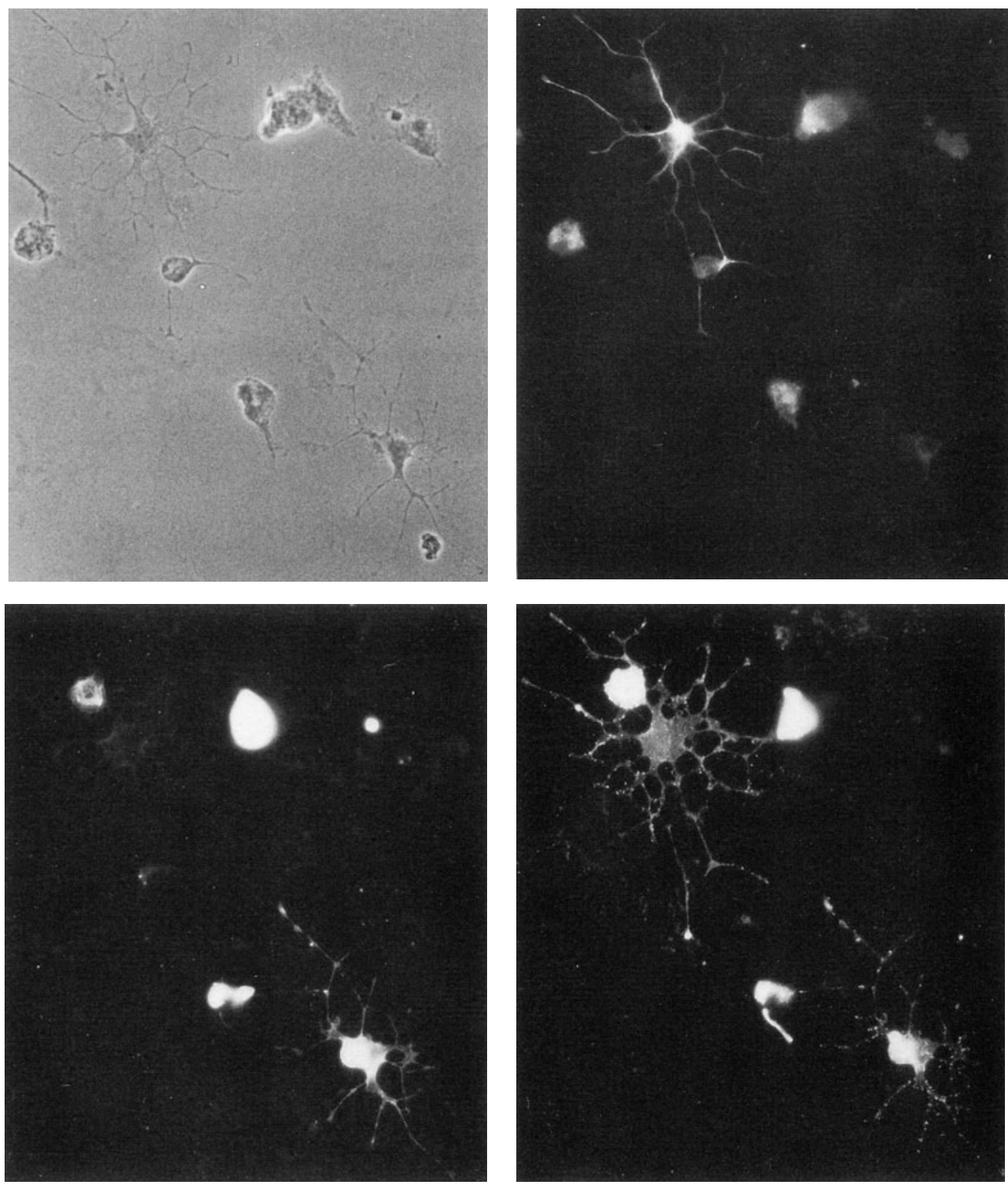

Figure 4. An oligodendrocyte (O4+ GC+ GFAP-) and a type 2 astrocyte (O4+ GC- GFAP+) isolated from spinal cords of 9 week old mice at the onset of remyelination (5 WPI). Cells were fixed at 3 days in vitro and processed for 3 -color immunofluorescence. Top left: phase contrast. Top right: GFAP. Bottom left: GC. Bottom right: 04 . 
We found an important increase, relative to controls, in the number of $0-2 A$ lineage cells that could be isolated and cultured from demyelinating tissues at three to five WPI. Cultures derived from demyelinating tissues also contained numerous microglial cells which were rarely encountered in controls. Within the $\mathrm{O}-2 \mathrm{~A}$ lineage population isolated from demyelinating tissues, there was a higher proportion of type 2 astrocytes and cells with a mixed oligodendrocyte-astrocyte phenotype, as compared to controls. The mixed phenotype cell, almost unique to remyelinating animals, was also identified in vivo in demyelinating animals, although rarely (Godfraind et al., 1989). This indicates a greater phenotypic plasticity in $\mathrm{O}-2 \mathrm{~A}$ lineage cells from these diseased animals. Such
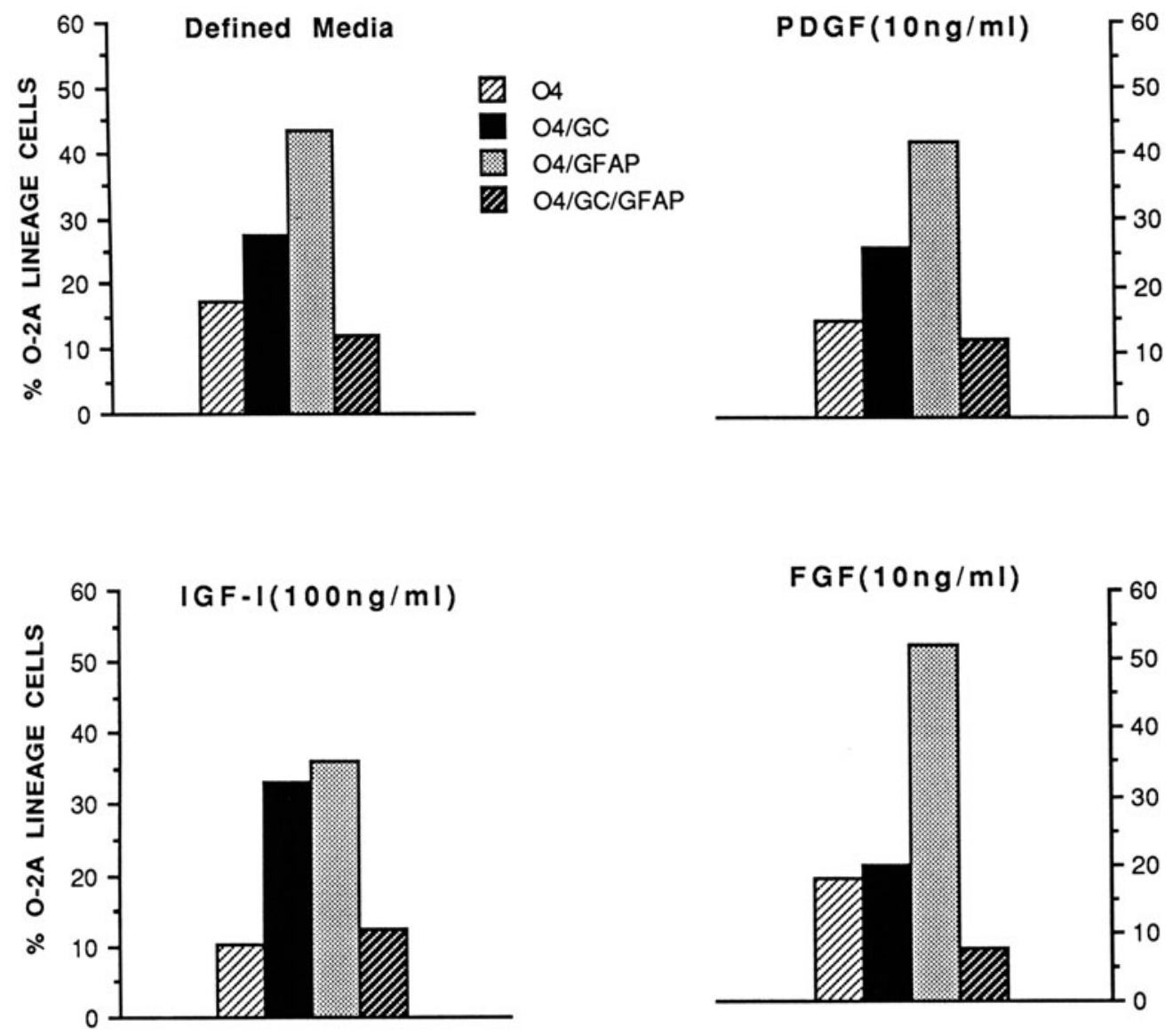

Figure 5. O-2A lineage cells were isolated from spinal cords of 9 week old mice (5 WPI). Growth factors were added to defined media after 1 day in vitro. Cells were fixed at 3 days in vitro and identified by 3-color immunofluorescence. 
behavior could be related to the release of a number of polypeptides in the lesions; for instance ciliary neurotrophic factor is increased in CNS tissues during regeneration (Nieto-Sampedro et al., 1983) and may transiently induce GFAP in O-2A progenitors (Lillien et al., 1988). The increased number of O-2A lineage cells isolated during demyelination is at least partially due to proliferation. Cultures derived from spinal cords of infected mice contained an increased proportion of tritiated thymidine-labeled $0-2 \mathrm{~A}$ lineage cells after a short in vivo or in vitro pulse. Dividing cells were rarely seen in control cultures. Thymidine incorporation was not markedly enhanced by addition of human PDGF, basic FGF or IGF1 (Amstrong et al., 1989). In these cultures the ratio of oligodendrocytes relative to type 2 astrocytes was higher in the presence of IGF-1, and was lower in the presence of basic FGF (figure 5) as was seen with cultured O-2A progenitors isolated from early development (see above). Thus, in this in vitro system, we can now study the conditions for O-2A lineage cells to proliferate and express phenotypic plasticity as they do in vivo in the course of demyelination and remyelination.

\section{Conclusions:}

Studies on glial O-2A progenitor cells in vitro suggest that an interaction between several different polypeptide growth factors may affect the process of $0-2 A$ lineage differentiation in vivo. FGF and PDGF are mitogenic for O-2A progenitor cells, and PDGF appears to control the timing of O-2A differentiation while FGF may block differentiation into oligodendrocytes. In contrast, IGF-1 promotes oligodendrocyte development. An O4+ O$2 \mathrm{~A}$ progenitor cell persists in the adult and may represent a self-renewing "stem" cell that proliferates in response to a demyelinating episode. The phenotype of adult O-2A lineage cells can also be modulated by some of these grovith factors. Thus polypeptide growth factors that are important for normal glial cell development may also have a role in the process of remyelination. Understanding the mechanisms regulating expression of these factors during development and disease will further our ability to intervene in demyelinating diseases in man.

\section{Acknowledgements:}

We thank Ray Rustin for excellent technical assistance. R.McK was supported by a senior fellowship from the US National Multiple Sclerosis Society. 


\section{References:}

Armstrong R, Friedrich VL Jr, Holmes KV, Dubois-Dalcq M (1988) In vitro analysis of neuroglial cells isolated during demyelination and remyelination. Soc Neurosci Abstr 14: 787

Armstrong R, Friedrich VL Jr, Holmes KV, Dubois-Dalcq M (1989) Proliferation and differentiation of neuroglial cells isolated during demyelination and remyelination. Ann NY Acad Sci (in press)

Aranella LS, Herndon RM (1984) Mature oligodendrocytes division following expeirmental demyelination in adult animals. Arch Neurology 41:1162-1165

Barde Y-A (1989) Trophic factors and neuronal survival. Neuron 2:1525-1534

Behar T, McMorris FA, Novotny EA, Barker JL, Dubios-Dalcq M (1988) Growth and differentiation properties of $0-2 A$ progenitors purified from rat cerebral hemispheres. J Neurosci Res 21:168-180

Besnard F, Perraud F, Sensenbrenner M, Labourdette G (1989) Effects of acidic and basic fibroblast growth factors on proliferation and maturation of cultured rat oligodendrocytes. Int $\mathrm{J}$ Develop Neurosci in press

Claesson-Welsh L, Eriksson A, Westermark B, Heldin C-H (1989) cDNA cloning and expression of the human A-type platelet-derived growth factor (PDGF) receptor establishes structural similarity to the B-type PDGF receptor. Proc Natl Acad Sci USA $86: 4917-4921$

Dubois-Dalcq M (1987) Characterization of a slowly proliferative cell along the oligodendrocyte differentiation pathway EMBO 6:2587-2595

Eccleston PA, Silberberg DH (1985) Fibroblast growth factor is a mitogen for oligodendrocytes in vitro. Dev Brain Res 21:315-318

Ferrara N, Ousley F, Gospodarowicz D (1988) Bovine brain astrocytes express basic fibroblast growth factor, a neurotropic and angiogenic mitogen. Brain Research 462:223-232

Finkelstein SP, Apostolides PJ, Caday CG, Prosser J, Philips MF, Klagsbrun M (1988) Increased basic fibroblast growth factor (bFGF) immunoreactivity at the site of local brain wounds. Brain Res 460:253-259

ffrench-Constant C, Raff MC (1986) Proliferating bipotential glial progenitor cells in adult rat optic nerve. Nature 319:499-502

Gard AL, Pfeiffer SE (1989) Oligodendrocyte progenitors isolated directly from developing telencephalon at a specific phenotypic stage myelinogenic potential in a defined environment. Development 106:119-132

Godfraind C, Friedrich VL, Holmes KV, Dubois-Dalcq M (1989) In vivo analysis of glial cell phenotypes during a viral demyelinating disease in mice. J Cell Biology (in press)

Hart CE, Forstrom JW, Kelly JD, Seifert RA, Smith RA, Ross R, Murray MJ, Bowen-Pope DF (1988) Two classes of PDGF receptor recognize different isoforms of PDGF. Science 240:1529-1534

Hart IK, Richardson WD, Heldin C-H, Westermark B, Raff MC (1989) PDGF receptors on cells of the oligodendrocyte-type-2 astrocyte $(\mathrm{O}-2 \mathrm{~A})$ cell lineage. Development 105:595-603

Hatten ME, Lynch M, Rydel RE, Sanchez J, Joseph-Silverstein J, Moscatelli D, Rifkin DB (1988) In vitro neurite extension by granule neurons is dependent upon astroglialderived fibroblast growth factor. Develop Biol 125:280-289 
Heldin C-H, Backstrom G, Ostman A, Hammacher A, Ronnstrand L, Rubin K, Nister M, Westermark B (1988) Binding of different dimeric forms of PDGF to human fibroblasts: evidence for two separate receptor types. EMBO J 7:1387-1393

Herndon RM, Price DL, Weiner LP (1977) Regeneration of oligodendroglia during recovery from demyelinating disease. Science 195:693-694

Hunter SE, Seidel MF, Bottenstein JE (1988) Response of neonatal and adult glial progenitors to neuronal cell line-derived mitogens. Soc Neurosci Abstr 14:321

Jordan C, Friedrich VL, deFerra F, Weismiller D, Holmes K, Dubois-Dalcq M (1989a) Differential exon expression in myelin basic protein transcripts during CNS remyelination. J Cellular and Molecular Neurobiol (in press)

Jordan C, Friedrich VL, Godfraind C, Holmes KV, Dubois-Dalcq M (1989b) Expression of viral and myelin gene transcripts in a murine demyelinating disease caused by a corona virus. Glia (in press)

Lillien LE, Sendtner M, Rohrer H, Hughes SM, Raff MC (1988) Type-2 astrocyte development in rat brain cultures is initiated by a CNTF-like protein produced by type1 astrocytes. Neuron 1:485-494

Levine JM (1989) Neuronal influences on glial progenitor cell development. Neuron $3: 103-113$

Ludwin SK, (1981) Pathology of demyelination and remyelination. In: Waxman SG, Ritchie JM (eds) Advances in neurology Vol 31. Demyelinating diseases. Raven Press, New York, 123-168

Ludwin SK, Sternberger NH (1984) An immunohistochemical study of myelin proteins during remyelination in the central nervous system. Acta Neuropathologica 63:240248

Matsui T, Heidaran M, Miki T, Popescu N, La Rochelle W, Krous M, Peirce J, Aaronson S (1989) Isolation of a novel receptor cDNA establishes the existence of two PDGF receptor genes. Science 243:800-804

McKinnon RD, Matsui TA, Aaronson S, Dubois-Dalcq, M (1989) FGF inhibits myelin gene expression and induces the PDGF-a receptor in differentiating $0-2 \mathrm{~A}$ glial progenitor cells. American Society for Cell Biology, 29th Annual Meeting

McMorris FA, Dubois-Dalcq M (1988) Insulin-like growth factor 1 promotes cell proliferation and oligodendroglial commitment in rat glial progenitor cells developing in vitro. J Neurosci Res 21:199-209

Nieto-Sampedro M, Manthorpe M, Barbin G, Varon S, Cotman CW (1983) Injury-induced neuronotrophic activity in adult rat brain: correlation with survival of delayed implants in the wound cavity. J Neuroscience 3:2219-2229

Pettmann B, Labourdette G, Weibel M, Sensenbrenner IA (1986) The brain fibroblast growth factor is localized in neurons. Neuroscience Letters 68:175-180

Pringle N, Collarini EJ, Mosley MJ, Heldin C-H, B Westermark B, Richardson WD (1989) PDGF A chain homodimers drive proliferation of bipotential (O-2A) glial progenitor cells in the developing rat optic nerve. EMBO $J$ 8:1049-1056

Raff MC (1989) Glial cell diversification in the rat optic nerve. Science 243:1450-1455

Raff MC, Abney ER, Fok-Seang J (1985) Reconstitution of a developmental clock in vitro: A critical role for astrocytes in the timing of oligodendrocytes. Cell 42:61-69

Raff MC, Lillien LE, Richardson WD, Burne JF, Noble MD (1988) Platelet-derived growth factor from astrocytes drives the clock that times oligodendrocyte development in culture. Nature 333:562-565

Raff MC, Miller RH, Noble M (1983) A glial progenitor cell that develops in vitro into an astrocyte or an oligodendrocyte depending on culture medium. Nature 303:390-396 
Raff MC, Williams BP, Miller RH (1984) The in vitro differentiation of a bipotential glial progenitor cell. EMBO 3:1857-1864

Richardson WD, Pringle N, Mosley JD, Westermark B, Dubois-Dalcq M (1988) A role for platelet-derived growth factor in normal gliogenesis in the central nervous system. Cell 53:303-319

Ross R, Raines EW, Bowen-Pope DF (1986) The biology of platelet-derived growth factor. Cell 46:155-169

Saneto RP, deVellis J (1985) Characterization of cultured rat oligodendrocytes proliferating in a serum-free, chemically defined medium. Proc Natl Acad Sci USA 82:3509-3513

Skoff R, Price D, Stocks A (1976) Electron microscopic autoradiographic studies of gliogenesis in rat optic nerve I cell proliferation. J Comp Neurol 169:291-312

Sommer I, Noble M (1986) Plasticity and commitment in oligodendrocyte development. Soc Neurosci Abstr 12:1585

Temple S, Raff MC (1986) Clonal analysis of oligodendrocyte development in culture: Evidence for a developmental clock that counts cell divisions. Cell 44:773-779

Van-Obberghen-Schilling E, Behar T, Sporn MB, Dubois-Dalcq M (1987) Signalling between type 1 astrocytes and their glial 0-2A progenitors: Modulation by transforning growth factor-beta (TGFB). J Cell Biol 105 (4) (Part 2):318a

Wolswijk G, Noble M (1989) Identification of an adult-specific glial progenitor cell. Development 105:387-400

Yarden Y, Escobedo JA, Kuang W-J, Yang-Feng TL, Daniel TO, Tremble PM, Chen EY, Ando ME, Harkins RN, Francke U, Fried VA, Ullrich A, Williams LT (1986) Structure of the receptor for platelet-derived growth factor helps define a family of closely related growth factor receptors. Nature 323:226-232

Zeller NK, Behar TN, Dubois-Dalcq M, Lazzarini RA (1985) The timely expression of myelin basic protein gene in cultured rat brain oligodendrocytes is independent of continuous neuronal influences. J Neurosci 5:2955-2962 